\title{
Partial harvesting in the Canadian boreal: Success will depend on stand dynamic responses
}

\author{
by H.C. Thorpe ${ }^{1,2}$ and S.C. Thomas ${ }^{1}$
}

\begin{abstract}
In the past 10 to 15 years, alternative silvicultural treatments involving partial harvesting have been developed for boreal forests, with the goal of achieving a balance between biodiversity maintenance and continued timber production. Most prior research has focussed on the impacts of partial harvesting on biological diversity, while stand dynamic responses remain little studied. In this paper we explore partial stand harvesting in the Canadian boreal-its rationale, current extent, and impact on stand dynamic patterns. Empirical studies from the boreal and elsewhere indicate that residual trees of many species respond to partial harvesting with enhanced growth, commonly showing a lagged response after which peak growth occurs five to 25 years following harvest. Post-harvest mortality is also prevalent but much more variable, with losses of residual trees ranging from nearly zero to more than $50 \%$ above background mortality rates in the initial years following harvest. With the exception of strip cutting in parts of northern Ontario and Quebec (HARP/CPPTM), operational partial harvesting in the Canadian boreal currently involves very low levels of retention. Available data suggest that such low retention levels, particularly when spatially dispersed, generally result in unacceptably high rates of post-harvest mortality, which are unlikely to be offset by increases in residual tree growth. There is an urgent need for development of spatially explicit stand simulation models that will allow accurate yield predictions for partial harvest systems to assess their feasibility in boreal forest management.
\end{abstract}

Key words: ecosystem management, natural disturbance emulation, boreal forest, partial cut, structural retention, growth response, windthrow, post-harvest mortality

\section{RÉSUMÉ}

Au cours des dix à quinze dernières années, des traitements sylvicoles alternatifs comprenant une coupe partielle ont été élaborés en forêt boréale, dans le but d'obtenir un équilibre entre le maintien de la biodiversité et la production continue de matière ligneuse. La majeure partie de la recherche réalisée à ce jour a porté sur les impacts de la coupe partielle sur la diversité biologique, tandis que les réactions au niveau de la dynamique du peuplement recevaient peu d'attention. Dans cet article, nous explorons la coupe partielle des peuplements dans les forêts boréales du Canada : le rationnel, le niveau actuel d'utilisation et les conséquences sur les patrons de dynamique des peuplements. Les études empiriques en provenance des forêts boréales et des autres forêts indiquent que les arbres résiduels de plusieurs espèces réagissent à la coupe partielle par un accroissement de la croissance, démontrant généralement une réaction déphasée suivie d'un pic de croissance survenant entre 5 et 25 ans après la récolte. La mortalité après coupe est également présente quoique plus variable, avec des pertes parmi les arbres résiduels avec des taux de zéro à plus de $50 \%$ de mortalité par rapport au milieu naturel au cours des premières années suivant la récolte. À l'exception des coupes par bandes dans le nord de l'Ontario et du Québec (HARP/CPPTM), la récolte partielle à grande échelle dans les forêts boréales comporte un très faible taux de rétention. Les données disponibles laissent entendre que de tels niveaux de rétention, spécialement lorsque dispersés dans l'espace, résultent généralement en des taux élevés totalement inacceptables de mortalité après coupe, qui ne seront vraisemblablement pas corrigés par la croissance des arbres résiduels. Il est urgent de développer des modèles de simulation explicite des peuplements dans l'espace qui permettront des prédictions précises du rendement dans le cas des modes de récolte partielle afin d'évaluer leur utilité en aménagement des forêts boréales.

Mots clés : aménagement écosystémique, simulation d'une perturbation naturelle, coupe partielle des forêts boréales, rétention structurelle, réaction de croissance, chablis, mortalité après coupe

\footnotetext{
${ }^{1}$ Faculty of Forestry, University of Toronto, 33 Willcocks St., Toronto, Ontario M5S 3B3.

${ }^{2}$ Corresponding author. E-mail: hilary.thorpe@utoronto.ca.
} 


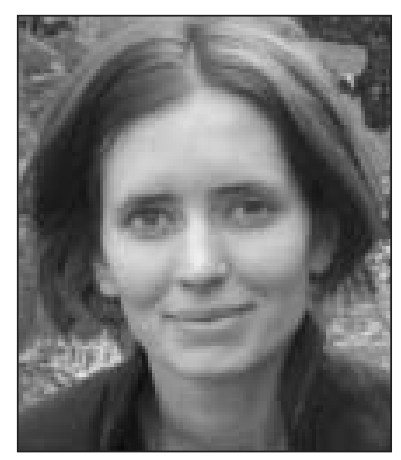

H.C. Thorpe

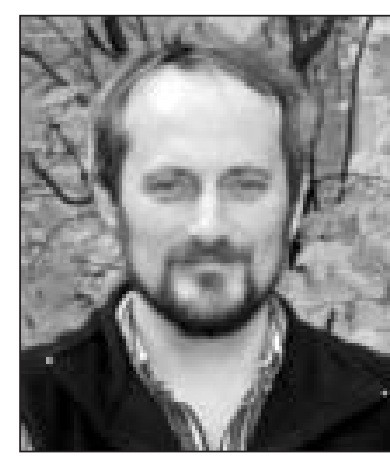

S.C. Thomas

\section{Introduction}

The boreal forest is undergoing a period of transformation, with changes ranging from alterations of the biophysical climate to the restructuring of northern communities in the wake of mill closures. Forest management practices are no exception to this trend. Management goals have broadened beyond simple production of a sustained supply of timber and, following the widespread adoption of ecosystem management principles, alternative treatments and silvicultural systems are emerging (e.g., Lieffers et al. 1996, Groot 2002). In some regions, large clearcuts, common in prior decades, have been replaced with various forms of "retention harvests," which retain residual trees in patches of varying size and spatial layout (Lance and Phinney 2001, Groot et al. 2005).

Historically, forestry and its primary tool, silviculture, focussed on converting natural forests from complex, multispecies, multi-storied, uneven-aged systems to monospecific, even-aged stands that were often considered easier to manage and more efficient than natural stands (Kohm and Franklin 1997). Terms such as "overmature" and "decadent," employed to describe trees or stands no longer displaying upward growth trajectories, remain in common use among foresters today (e.g., Franklin et al. 2002, Harvey et al. 2002) and are evidence of this history. Across many forest systems including the boreal, the practice of reducing complex forests to "ecomachines" aimed at producing one or a few commodities has resulted in a myriad of environmental and social problems (see e.g., Prudham 2005). From an ecological standpoint, the most troubling are declines and losses of species.

It is thus not surprising that the concept of ecosystem management has spread so quickly and widely as a framework by which to guide natural resource management. The most common application of ecosystem management is "natural disturbance emulation" (NDE), which uses historical (i.e., pre-industrial) disturbance regimes as a template for forest management (Attiwill 1994, Galindo-Leal and Bunnell 1995, Franklin et al. 2002). NDE is a "coarse filter" approach to biodiversity conservation, and is based on the hypothesis that if forestry practices produce stands and landscapes that are similar to their historical counterparts in both composition and structure, diversity and ecosystem function will be maintained (Franklin 1993, Bergeron et al. 2001).

In boreal forests, fire is the most important natural disturbance, consuming up to three million hectares per year in Canada alone (Amiro et al. 2001) and driving much of the pattern of landscape variability (Bergeron 2000). As a result, natural disturbance emulation was originally equated with clearcutting on a 60 - to 100 -year rotation to mimic regular, stand-replacing fires (McRae et al. 2001). There are, however, many important differences between fire and clearcutting, at both the stand and landscape scales. For example, fires, in contrast to clearcuts, leave behind live trees and snags that are incorporated into regenerating stands, and provide wildlife habitat, appropriate microclimatic conditions for tree seedling establishment, and nutrient sources (McRae et al. 2001). In addition, regulated even-aged management truncates the patch-size and age-class distributions of managed landscapes at a much smaller range than was historically found (Bergeron et al. 1999, McRae et al. 2001). Of specific concern is the targeted loss of old stands that occurs through management activities, since it is these stands that are generally associated with peak biodiversity levels (Bergeron and Harvey 1997, McRae et al. 2001). In regions where fire cycles are long, natural development of uneven-aged stands is common, and forest management activities cause a particularly marked discrepancy in the proportion of old stands found on managed versus unmanaged forest landscapes (Lesieur et al. 2002, Harper et al. 2003).

Natural dynamics-based silviculture, or multi-cohort management (Bergeron and Harvey 1997, Harvey et al. 2002), has been proposed as an approach that recognizes differences between historical and conventionally managed forests, and aims at incorporating the complexity found in unmanaged forests by varying silvicultural treatments. At the stand level, the primary proposed change, apart from retention of important ecological features in all cutblocks, is a move towards increased use of partial harvesting. It is presumed here that by retaining adequate structure, partially harvested stands will behave more like old, diverse (secondor third-cohort) stands by maintaining biodiversity and other ecosystem services commonly lost, temporarily or permanently, through clearcutting practices (Harvey et al. 2002).

To date, most research examining responses to partial harvesting in the boreal has focussed on biodiversity, specifically looking at how levels of retention affect taxa of conservation or ecological concern, such as small mammals (Moses and Boutin 2001, Fisher and Bradbury 2006), birds (Lance and Phinney 2001, Vanderwel et al. in review), insects (Gandhi et al. 2004, Deans et al. 2005, Martikainen et al. 2006), ectomycorrhizal fungi (Dahlberg et al. 2001, Lazaruk et al. 2005), understorey plants (Jalonen and Vanha-Majamaa 2001, Bradbury 2004), and coarse woody debris, an important habitat substrate (Deans et al. 2003, Lilja et al. 2005). Most studies find that partial cuts maintain levels of biodiversity higher than those found in clearcuts but lower than those of uncut stands. Biodiversity levels in partial cuts, however, are commonly disproportionate to retention level. For example, similar bird species richness and abundances were found in uncut compared with $15 \%$ to $22 \%$ retention cuts, while both richness and abundance declined significantly in clearcuts (Lance and Phinney 2001).

While early responses of many species to partial harvest appear positive, it remains unclear whether these levels of diversity will persist throughout the length of a rotation. In addition, the issue of timber production rates in partial cuts, quantified in large part by residual tree responses, has received very little attention. Thus, the degree to which partially cut stands will continue either to produce timber or to maintain biodiversity levels over the long term remains 
unknown, and important questions remain: What intensity of partial harvesting is required for its economic feasibility? Will most species be able to persist at that level of retention? Or, more fundamentally, is it economically possible to produce a sustainable supply of timber from partially harvested stands in the boreal forest? Information about future yields is required to answer many of these questions, but accurate yield prediction under partial harvesting is not feasible until residual tree growth and mortality responses to partial harvest are quantified.

\section{A Note on Terminology}

The Canadian Forest Service (CFS) defines partial harvest as "any cutting in which only part of the stand is harvested" (1999). No minimum level of retention is specified. More commonly, "partial harvest" is used to describe relatively high-retention treatments aimed at emulating natural succession or disturbance processes such as stand break-up or insect outbreak (e.g., Bergeron and Harvey 1997), while live-tree retention within clearcuts is often not considered true partial harvesting. In this paper, we use the CFS definition, and include all relevant studies examining residual tree responses to harvest. Here we do not intend to disregard the debate concerning the terminology of alternative silviculture (see Franklin et al. 1997, Mitchell and Beese 2002, Groot et al. 2005) but rather put it aside in order to draw from a larger body of literature for the purposes of this paper.

\section{Extent of Partial Harvesting in Canada's Boreal Forest}

Many jurisdictions in Canada, including Ontario (OMNR 2001) and British Columbia (BCMOF 1995), have recently implemented policies that require the retention of live trees in all harvest blocks. In Alberta, retention systems including aspen overstorey harvest with understorey white spruce protection have been implemented on smaller scales (Lieffers et al. 1996). However, operational retention rates across Canada are in general very low $(<10 \%)$.

Examples of operational-scale partial harvesting in the boreal with higher rates of retention remain scarce. Harvest with Advance Regeneration Protection (HARP; termed CPPTM-Coupe avec Protection de Petites Tiges Marchandes - in Quebec) appears to be the one major exception. First implemented in the mid-1990s in uneven-aged black spruce stands in northeastern Ontario and Quebec (MacDonell and Groot 1997), HARP is characterized by alternating clearcut and leave strips in which diameter-limit cutting is carried out (Tallman 1998). HARP was initially designed to reduce post-harvest regeneration costs, and not to emulate natural disturbance, but it remains the sole example of partial harvesting in the boreal that has been carried out over a large spatial scale for more than a decade.

In addition to operational-scale partial harvesting, a number of large-scale silviculture trials aimed at exploring potential alternative treatments for boreal forest management have been established (Table 1). In general, these experiments examine the effects of multiple intensities of partial harvesting and/or spatial layout of retention. Research from these trials has the potential to address many questions about partial harvesting in the boreal, and there has been a great deal of research output from the EMEND and FERLD (Table 1) sites in particular, most of which has focussed on biodiversity and ecosystem processes.
Residual Tree Growth Responses to Partial Harvest It is well known that small, young trees display increases in growth following release from competition; long-established practices such as thinning are predicated on this fact (Assmann 1970). Large and/or old trees, in contrast, had not traditionally been thought capable of responding to competition reduction. The shelterwood system, for example, retains a number of mature trees to shelter the establishing tree seedling layer, but the potential for these residual trees to increase in wood volume during the period between the first and subsequent cut(s) has not generally been considered (Smith et al. 1997). However, recent studies report that mature individuals of a number of tree species show positive growth responses to reductions in stand density. The general pattern, emerging across a number of regions, consists of three stages: 1) a lag period immediately after harvest during which there is no change in growth (usually two to five years), 2) a gradual increase up to a peak in growth response (usually within a decade of harvest), and 3) a period of declining growth towards pre-harvest levels. It is unclear how long elevated growth rates will continue, but there is evidence that they can persist for decades after harvest in some systems (Latham and Tappeiner 2002, Bevilacqua et al. 2005).

In the boreal forest, most research has focused on growth responses of tree seedlings and saplings to partial harvest (e.g., Bourgeois et al. 2004, MacDonald et al. 2004), but a few studies have examined responses of mature residual trees. Following a two-year lag, Youngblood (1991) reported radial growth increases up to $164 \%$ eight years after a shelterwood seed cut in a 172-year-old even-aged white spruce (Picea glauca) stand in Alaska. Two-year lags were also detected in studies of black spruce (Picea mariana), after which twofold increases in growth were reached eight to ten years following historical (horse logging) and more recent (HARP) partial harvests (Groot and Hökkä 2000, Thorpe et al. in review). Bebber et al. (2004) also found an approximately $60 \%$ increase in white pine (Pinus strobus) radial growth subsequent to a three-year time lag that followed a structural retention harvest in the boreal and Great Lakes-St. Lawrence forest transition zone.

In temperate regions, similar patterns of delay and subsequent response have been found in ponderosa pine (Pinus ponderosa; McDowell et al. 2003), Douglas-fir (Pseudotsuga menziesii; Latham and Tappeiner 2002), sugar maple (Acer saccharum; Jones and Thomas 2004), and white pine (Bevilacqua et al. 2005). The magnitude of post-harvest responses varies among species and silvicultural treatments with $60 \%$ increases found after single-tree selection in sugar maple forests, (Jones and Thomas 2004), 45\%-60\% increases found after density reduction cuts in Douglas-fir (Latham and Tappeiner 2002, Walter and Maguire 2004), and $100 \%-300 \%$ increases found in studies of ponderosa and white pine (Latham and Tappeiner 2002, McDowell et al. 2003, Bevilacqua et al. 2005).

Clearly, mature individuals of a number of commercially important tree species in the boreal forest and elsewhere are capable of responding to reduction in competition. Presumably this response is a result of elevated availability of resources such as light, nutrients and water; the particular limiting resource is likely to vary across forest regions. Many studies report large variation in individual-tree growth responses, even among members of the same species in the 
Table 1. Descriptions of partial harvesting experimental trials in the Canadian boreal forest ${ }^{\mathrm{a}}$.

\begin{tabular}{|c|c|c|c|c|c|}
\hline Name & Location & $\begin{array}{l}\text { Governing } \\
\text { body }\end{array}$ & $\begin{array}{l}\text { Year } \\
\text { established }\end{array}$ & $\begin{array}{l}\text { Ecozone; } \\
\text { Forest type }\end{array}$ & $\begin{array}{l}\text { Silvicultural } \\
\text { treatments }\end{array}$ \\
\hline Muskeg River Silvicultural Study & $\begin{array}{l}\text { Southwestern } \\
\text { Northwest } \\
\text { Territories }\end{array}$ & $\begin{array}{l}\text { Canadian } \\
\text { Forest Service }\end{array}$ & 1994 & $\begin{array}{l}\text { Taiga plains; } \\
\text { Mixedwood }\end{array}$ & $\begin{array}{l}\text { clearcut; strip } \\
\text { cut; patch cut }\end{array}$ \\
\hline $\begin{array}{l}\text { Hotchkiss River Mixedwood } \\
\text { Timber Harvesting Study }\end{array}$ & $\begin{array}{l}\text { Northwestern } \\
\text { Alberta }\end{array}$ & $\begin{array}{l}\text { Canadian } \\
\text { Forest Service }\end{array}$ & 1993 & $\begin{array}{l}\text { Boreal plains; } \\
\text { Mixedwood }\end{array}$ & $\begin{array}{l}\text { clearcut; uncut; } \\
\text { shelterwood; strip cut }\end{array}$ \\
\hline $\begin{array}{l}\text { Ecosystem Management by } \\
\text { Emulating Natural Disturbance } \\
\text { (EMEND) }\end{array}$ & $\begin{array}{l}\text { Northwestern } \\
\text { Alberta }\end{array}$ & $\begin{array}{l}\text { University } \\
\text { of Alberta }\end{array}$ & 1998 & $\begin{array}{l}\text { Boreal plains; } \\
\text { Mixedwood }\end{array}$ & $\begin{array}{l}\text { clearcut; uncut; partial } \\
\text { cut with } 10,20,50, \\
\text { and } 75 \% \text { retention }\end{array}$ \\
\hline $\begin{array}{l}\text { Alcott Creek Forest Management } \\
\text { Demonstration Area }\end{array}$ & $\begin{array}{l}\text { Central } \\
\text { Saskatchewan }\end{array}$ & $\begin{array}{l}\text { Mistik } \\
\text { Management Ltd. }\end{array}$ & 1993 & $\begin{array}{l}\text { Boreal plains; } \\
\text { Mixedwood }\end{array}$ & $\begin{array}{l}\text { two-stage aspen } \\
\text { harvesting (protecting } \\
\text { small white spruce) }\end{array}$ \\
\hline $\begin{array}{l}\text { Black Sturgeon Boreal } \\
\text { Mixedwood Research Site }\end{array}$ & $\begin{array}{l}\text { Northwestern } \\
\text { Ontario }\end{array}$ & $\begin{array}{l}\text { Canadian } \\
\text { Forest Service }\end{array}$ & 1993 & $\begin{array}{l}\text { Boreal shield; } \\
\text { Mixedwood }\end{array}$ & $\begin{array}{l}\text { clearcut; uncut; patch } \\
\text { cut; partial cut with } \\
33 \% \text { retention }\end{array}$ \\
\hline $\begin{array}{l}\text { Wade Lake Uneven-aged } \\
\text { Silviculture Trial }\end{array}$ & $\begin{array}{l}\text { Northeastern } \\
\text { Ontario }\end{array}$ & $\begin{array}{l}\text { Lake Abitibi } \\
\text { Model Forest }\end{array}$ & 1994 & $\begin{array}{l}\text { Boreal shield; } \\
\text { Black spruce }\end{array}$ & $\begin{array}{l}\text { 12-, 15-, and 18-cm } \\
\text { diameter limit cuts; uncut }\end{array}$ \\
\hline $\begin{array}{l}\text { Forêt d'enseignement et de } \\
\text { recherche du lac Duparquet } \\
\text { (FERLD)/ Lake Duparquet } \\
\text { Research and Teaching Forest }\end{array}$ & $\begin{array}{l}\text { Northwestern } \\
\text { Quebec }\end{array}$ & $\begin{array}{l}\text { Université du } \\
\text { Québec en } \\
\text { Abitibi- } \\
\text { Témiscamingue }\end{array}$ & 1998 & $\begin{array}{l}\text { Boreal shield; } \\
\text { Mixedwood }\end{array}$ & $\begin{array}{l}\text { clearcut; uncut; partial } \\
\text { cut with } 33 \text { and } 66 \% \\
\text { retention }\end{array}$ \\
\hline
\end{tabular}

aSources: Navratil et al. 1994, Scarratt 2001, Bock and Van Rees 2002, Groot 2002, Bourgeois et al. 2004, FERNS 2006.

${ }^{b}$ Extensive areas of the trial area were burned by wildfire in 1999 .

same stand. These differences are likely to be related to smallscale, neighbourhood influences such as the amount of release different trees experience, and point to the importance of using individual-based, spatially explicit models to predict stand-level growth responses to partial harvest.

Remaining in question is the mechanism behind the lag in growth response, a phenomenon that appears widespread. One possibility is that trees allocate resources to root growth before diameter growth, as was reported in a study of white spruce (Urban et al. 1994). Another study reported shifts in carbon allocation along white pine tree boles after harvest, likely a response to increased wind exposure (Bevilacqua et al. 2005). Slow photosynthetic acclimation, evidence for which was found in a study of responses of canopy foliage in sugar maple (Jones and Thomas 2007), may also help to explain time lags.

\section{Post-Harvest Tree Mortality}

Of major concern for proponents of partial harvesting in the boreal and elsewhere is elevated mortality of residual trees following harvest. Residual trees are often physically damaged during logging operations (e.g., Moore et al. 2002) and are subject to stresses involving abrupt changes in wind exposure, light, temperature, and humidity, all of which may lead to increased mortality. Some level of post-harvest mortality is inevitable, and perhaps even desirable, since snags and downed logs have high habitat value (Harmon et al. 1986). But whether viewed from an ecosystem process or a timber production standpoint, retention systems will be acceptable to forest managers only if residual tree mortality rates remain low. Coates (1997) suggests that a partial harvest treatment should be considered a failure if the residual tree mortality rate progresses beyond $10 \%$. At present, however, the rate, time course, and causes of post-harvest mortality remain mostly unquantified (Ruel 1995).

There have been a handful of studies examining post-harvest mortality following partial harvest in the boreal. Windthrow rates reached up to $17 \%$ of residual basal area in the first four years following a 50\% retention partial cut in an Ontario mixedwood stand (MacDonald and Thompson 2003) while in Finland, $40 \%$ of residual Norway spruce (Picea abies) stems that were retained in aggregates had been uprooted two years after harvest (Hautala et al. 2004). In Quebec, windthrow rates of black spruce after strip clearcutting were found to range from $8.8 \%$ to $20.2 \%$ (Ruel 1989) and balsam fir (Abies balsamea) experienced $5.6 \%$ to $18.6 \%$ 
windthrow six years after shelterwood cutting (Ruel et al. 2003). Cumulative windthrow losses of up to $80 \%$ were reported in riparian buffer strips in northern Quebec ten years after harvesting, with species-specific differences in susceptibility: balsam fir was at highest risk, followed by white spruce, black spruce, and paper birch (Betula papyrifera; Ruel et al. 2001).

Most information concerning mortality following partial harvests pertains to the U.S. Pacific Northwest and British Columbia (BC). Coates (1997) found a 1.1\% increase in windthrow mortality two years after harvest at the Date Creek Silvicultural site in interior BC, while rates were elevated by a mere $0.2 \%$ to $1.2 \%$ in a subalpine forest 2.7 years after harvest (Huggard et al. 1999). Similarly, there was no significant increase in mortality found after high-retention historical and recent partial cutting in southwestern Alaska (Deal et al. 2002). High levels of post-harvest mortality have also been reported. For example, about $25 \%$ of residual trees were lost within the first three years after dispersed retention harvest in the Montane Alternative Silviculture Systems (MASS) experiment on Vancouver Island (Beese and Arnott 1999, Beese and Bryant 1999), while $16 \%$ of residual trees were windthrown between one and six years after variable retention cutting in Clayoquot sound (Scott and Mitchell 2005). Mortality reached $14 \%$ in low-retention treatments in an Oregon experiment (Walter and Maguire 2004), while the Demonstration of Ecosystem Management Options study in Oregon and Washington reported increasing mortality with harvesting intensity and dispersed rather than aggregated retention (Maguire et al. 2006). The highest mortality was found in $15 \%$ dispersed retention treatments, where rates were elevated ten times above background in the first five years after harvest (Maguire et al. 2006).

Outside the boreal and Pacific Northwest regions, studies of post-harvest tree mortality remain rare. Mortality rates were $0.2 \%$ to $3.3 \%$ higher following experimental single-tree selection cuts in hardwood stands in Ontario (Caspersen 2006), but this represented losses due to felling damage only, as no skidding was carried out. Predicted mortality rates are thus conservative. Negligible post-harvest mortality was found following group selection in New Zealand (Wiser et al. 2005), and reduced-impact logging caused a $1.1 \%$ increase in mortality in an Indonesian tropical forest (Sist and NguyenThe 2002).

Nearly all studies to date have presented only a snapshot of mortality losses at a given point in time. Assessments have mostly occurred two or three years following operations, but elevated rates of mortality can persist beyond a decade (Ruel et al. 2001, Caspersen 2006). Clearly, the time course of postharvest mortality is essential to inferring total volume loss: a $1 \%$ increase in mortality may be a negligible effect if it persists for one or two years, but a serious concern if it persists for 10 to 20 years. This remains a critical issue to be addressed before the severity of post-harvest mortality can be determined.

In sum, across forest regions and harvest treatments, tree mortality increases following partial harvest, but the magnitude of this response varies widely. This result contrasts with the more consistent pattern of growth response to harvest. Studies consistently indicate that post-harvest mortalityparticularly windthrow-is highest with increasing harvest- ing intensity and dispersion of residuals. The high variation in post-harvest mortality rates can be partially explained by these patterns; however, our mechanistic understanding of the phenomenon remains poor, and windthrow per se is only part of the picture. Additional potential mechanisms include fungal pathogens, such as root-rot fungi (Whitney et al. 2002), which may infect harvest-damaged trees and display increased rates of infection after harvest. These pathogens could be an important driver behind windthrow in some systems. Water stress induced through increased wind sway of suppressed trees, soil compaction, and changes in microclimate may also contribute to elevated mortality (Liu et al. 2003, Bladon et al. 2006). In one study, Ruel et al. (2003) determined that the most important factor influencing windthrow occurrence was the presence of adjacent clearcuts, which funnelled wind into partial harvests. Some or much of the observed variation among sites, therefore, is likely related to landscape, rather than stand-level, factors.

\section{Conclusion}

The general finding of large growth responses of residual trees to partial harvest in the boreal forest and elsewhere is positive from a management standpoint. However, early results show variable and often very high rates of post-harvest mortality, particularly when retention levels are low. This finding is troublesome since retention levels in operational practice remain on average much lower than those used in silvicultural trials. It appears that residual tree mortality will be the critical element that determines success or failure of partial harvests: if rates are low, increased tree growth following harvest could result in acceptable timber production rates. Alternatively, if mortality is high, it is unlikely that partial harvests will be able to produce a sustainable supply of timber, and provision of wildlife habitat and other ecosystem services will be transient. Until these stand dynamic responses to partial harvest are incorporated into growth and yield models, it will not be possible to determine quantitatively the implications of adopting alternative silvicultural practices in the boreal forest.

Modelling dynamic responses to harvest in complexstructured stands requires a move away from simple yield tables to the use of spatially explicit, individual-based stand simulation models (e.g., SORTIE-ND: Canham et al. 2004). Although complex, these models in principle permit the exploration of yield and/or habitat consequences of various harvesting regimes, including retention levels and patterns. It should be noted, however, that the structure of SORTIE-ND and other models make important assumptions that are clearly contradicted by empirical work on post-harvest stand dynamics. In particular, time lags and growth responses are not predicted, and in general, such models also assume that decreases in local density of neighbouring trees always result in reduced mortality through decreased local competition. Some modification of the structure of existing individualbased models thus appears essential in order to allow accurate predictions of stand dynamics following partial stand harvests in the boreal and other forest regions. These predictions will be critical for assessing the yield and habitat ramifications of partial harvesting, and for evaluating the implications of applying alternative silviculture in the Canadian boreal over the long term. 


\section{Acknowledgements}

We thank the Lake Abitibi Model Forest for its support and the advice of two anonymous reviewers, whose comments helped to improve the manuscript.

\section{References}

Amiro, B.D., J.B. Todd, B.M. Wotton, K.A. Logan, M.D. Flannigan, B.J. Stocks, J.A. Mason, D.L. Martell and K.G. Hirsch. 2001. Direct carbon emissions from Canadian fires, 1959-1999. Can. J. For. Res. 31: 512-525.

Assmann, E.A. 1970. The principles of forest yield study; studies in the organic production, structure, increment, and yield of forest stands. Trans. S.H. Gardiner. Oxford Pergamon Press. London. 506 p. Attiwill, P.M. 1994. The disturbance of forest ecosystems: the ecological basis for conservation management. For. Ecol. Manag. 63: 247-300.

Bebber, D.P., S.C. Thomas, W.G. Cole and D. Balsillie. 2004. Diameter increment in mature eastern white pine Pinus strobus L. following partial harvest of old-growth stands in Ontario, Canada. Trees 18: 29-34.

Beese, W.J. and J.T. Arnott. 1999. Montane Alternative Silvicultural Systems (MASS): Establishing and managing a multi-disciplinary, multi-partner research site. For. Chron. 75: 413-416.

Beese, W.J. and A.A. Bryant. 1999. Effect of alternative silvicultural systems on vegetation and bird communities in coastal montane forests of British Columbia, Canada. For. Ecol. Manag. 115: 231-242. Bergeron, Y. 2000. Species and stand dynamics in the mixed woods of Quebec's southern boreal forest. Ecology 81: 1500-1516.

Bergeron, Y., S. Gauthier, V. Kafka, P. Lefort and D. Lesieur. 2001. Natural fire frequency for the eastern Canadian boreal forest: consequences for sustainable forestry. Can. J. For. Res. 31: 384-391.

Bergeron, Y. and B. Harvey. 1997. Basing silviculture on natural ecosystem dynamics: an approach applied to the southern boreal mixedwood forest of Quebec. For. Ecol. Manag. 92: 235-242.

Bergeron, Y., B. Harvey, A. Leduc and S. Gauthier. 1999. Forest management guidelines based on natural disturbance dynamics: Standand forest-level considerations. For. Chron. 75: 49-54.

Bevilacqua, E., D. Puttock, T.J. Blake and D. Burgess. 2005. Longterm differential stem growth responses in mature eastern white pine following release from competition. Can. J. For. Res. 35: 511-520.

Bladon, K.D., U. Silins, S.M. Landhausser and V.J. Lieffers. 2006. Differential transpiration by three boreal tree species in response to increased evaporative demand after variable retention harvesting. Agr. Forest Meteorol. 138: 104-119.

Bock, M.D. and K.C.J. Van Rees. 2002. Forest harvesting impacts on soil properties and vegetation communities in the Northwest Territories. Can. J. For. Res. 32: 713-724.

Bourgeois, L., C. Messier and S. Brais. 2004. Mountain maple and balsam fir early response to partial and clear-cut harvesting under aspen stands of northern Quebec. Can. J. For. Res. 34: 2049-2059.

Bradbury, S. 2004. Understorey plant communities in boreal cutblocks with different sizes and numbers of residual tree patches. Can. J. For. Res. 34: 1220-1227.

British Columbia Ministry of Forests (BCMOF). 1995 The Forest Practices Code of British Columbia Act, Biodiversity Guidebook. Queen's Printer. Victoria, British Columbia.

Canadian Forest Service, 1999. Silvicultural Terms in Canada, $2^{\text {nd }}$ ed. Natural Resources Canada, Ottawa [0nline]. Available at http://nfdp.ccfm.org/silvaterm/silvi_e/silvitermintroe.htm.

Canham, C.D., P.T. LePage and K.D. Coates. 2004. A neighborhood analysis of canopy tree competition: effects of shading versus crowding. Can. J. For. Res. 34: 778-787.

Caspersen, J.P. 2006. Elevated mortality of residual trees following single-tree felling in northern hardwood forests. Can. J. For. Res. 36: 1255-1265.

Coates, K.D. 1997. Windthrow damage 2 years after partial cutting at the Date Creek silvicultural systems study in the Interior Cedar-
Hemlock forests of northwestern British Columbia. Can. J. For. Res. 27: 1695-1701.

Dahlberg, A., J. Schimmel, A.F.S. Taylor and H. Johannesson. 2001. Post-fire legacy of ectomycorrhizal fungal communities in the Swedish boreal forest in relation to fire severity and logging intensity. Biol. Cons. 100: 151-161.

Deal, R.L., J.C. Tappeiner and P.E. Hennon. 2002. Developing silvicultural systems based on partial cutting in western hemlock-Sitka spruce stands of southeast Alaska. Forestry 75: 425-431.

Deans, A.M., J.R. Malcolm, S.M. Smith and M.I. Bellocq. 2005. Edge effects and the responses of aerial insect assemblages to structuralretention harvesting in Canadian boreal peatland forests. For. Ecol. Manag. 204: 249-266.

Deans, A.M., J.R. Malcolm, S.M. Smith and T.J. Carleton. 2003. A comparison of forest structure among old-growth, variable retention harvested, and clearcut peatland black spruce (Picea mariana) forests in boreal northeastern Ontario. For. Chron. 79: 579-289.

FERNS 2006. Forest Ecosystem Research Network of Sites (FERNS) website. Canadian Forest Service, Natural Resources Canada [online]. Available at www.pfc.cfs.nrcan.gc.ca/ecology/ferns.

Fisher, J.T. and S.M. Bradbury. 2006. Understorey protection harvest expedites recolonisation of boreal forest stands by North American red squirrels. For. Ecol. Manag. 234: 40-47.

Franklin, J.F. 1993. Preserving biodiversity: species, ecosystems or landscapes. Ecol. Appl. 3: 202-205.

Franklin, J.F., D.R. Berg, D.A. Thornburg and J.C. Tappeiner. 1997. Alternative silvicultural approaches to timber harvesting: variable retention harvest systems. In K.A. Kohm and J.F. Franklin (eds.). Creating a forestry for the $21^{\text {st }}$ Century: the science of ecosystem management. pp. 111-139. Island Press, Washington, DC.

Franklin, J.F., T.A. Spies, R. Van Pelt, A.B. Carey, D.A. Thornburgh, D.R. Berg, D.B. Lindenmayer, M.E. Harmon, W.S. Keeton, D.C. Shaw, K. Bible and J.Q. Chen. 2002. Disturbances and structural development of natural forest ecosystems with silvicultural implications, using Douglas-fir forests as an example. For. Ecol. Manag. 155: 399-423.

Galindo-Leal, C. and F.L. Bunnell. 1995. Ecosystem management: implications and opportunities of a new paradigm. For. Chron. 71: 601-606.

Gandhi, K.J.K., J.R. Spence, D.W. Langor, L.E. Morgantini and K.J. Cryer. 2004. Harvest retention patches are insufficient as stand analogues of fire residuals for litter-dwelling beetles in northern coniferous forests. Can. J. For. Res. 34: 1319-1331.

Groot, A. 2002. Is uneven-aged silviculture applicable to peatland black spruce (Picea mariana) in Ontario, Canada? Forestry 75: 437-442.

Groot, A. and H. Hökkä. 2000. Persistence of suppression effects on peatland black spruce advance regeneration after overstory removal. Can. J. For. Res. 30: 753-760.

Groot, A., J.-M. Lussier, A.K. Mitchell and D.A. MacIsaac. 2005. A silvicultural systems perspective on changing Canadian forestry practices. For. Chron. 81: 50-55.

Harmon, M.E., J.F. Franklin, F.J. Swanson, P. Sollins, S.V. Gregory, J.D. Lattin, N.H. Anderson, S.P. Cline, N.G. Aumen, J.R. Sedell, G.W. Lienkaemper, K. Cromack Jr. and K.W. Cummins. 1986. Ecology of coarse woody debris in temperate ecosystems. Adv. Ecol. Res. 15: 133-302.

Harper, K., C. Boudreault, L. DeGrandpré, P. Drapeau, S. Gauthier and Y. Bergeron. 2003. Structure, composition and diversity of oldgrowth black spruce boreal forest of the Clay Belt region in Quebec and Ontario. Environ. Rev. 11: S79-S98.

Harvey, B.D., A. Leduc, S. Gauthier and Y. Bergeron. 2002. Standlandscape integration in natural disturbance-based management of the southern boreal forest. For. Ecol. Manag. 155: 369-385.

Hautala, H., J. Jalonen, S. Laaka-Lindberg and I. Vanha-Majamaa. 2004. Impacts of retention felling on coarse woody debris (CWD) in mature boreal spruce forests in Finland. Biodivers. Conserv. 13: 1541-1554. 
Huggard, D.J., W. Klenner and A. Vyse. 1999. Windthrow following four harvest treatments in an Engelmann spruce - subalpine fir forest in southern interior British Columbia, Canada. Can. J. For. Res. 29: 1547-1556.

Jalonen, J. and I. Vanha-Majamaa. 2001. Immediate effects of four different felling methods on mature boreal spruce forest understorey vegetation in southern Finland. For. Ecol. Manag. 146: 25-34.

Jones, T.A. and S.C. Thomas. 2004. The time course of diameter increment responses to selection harvests in Acer saccharum. Can. J. For. Res. 34: 1525-1533.

Jones, T.A. and S.C. Thomas. 2007. Leaf-level acclimation to gap creation in mature Acer saccharum trees. Tree Physiol. 27: 281-290.

Kohm, K.A. and J.F. Franklin. Introduction. In K.A. Kohm and J.F. Franklin (eds.). Creating a Forestry for the $21^{\text {st }}$ Century: The Science of Ecosystem Management. pp. 1-9. Island Press, Washington, DC. Lance, A.N. and M. Phinney. 2001. Bird responses to partial retention timber harvesting in central interior British Columbia. For. Ecol. Manag. 142: 267-280.

Latham, P. and J. Tappeiner. 2002. Response of old-growth conifers to reduction in stand density in western Oregon forests. Tree Physiol. 22: 137-146.

Lazaruk, L.W., G. Kernaghan, S.E. MacDonald and D. Khasa. 2005. Effects of partial cutting on the ectomycorrhizae of Picea glauca forests in northwestern Alberta. Can. J. For. Res. 35: 1442-1454.

Lesieur, D., S. Gauthier and Y. Bergeron. 2002. Fire frequency and vegetation dynamics for the south-central boreal forest of Quebec, Canada. Can. J. For. Res. 32: 1996-2009.

Lieffers, V.J., R.B. Macmillan, D. MacPherson, K. Branter and J.D. Stewart. 1996. Semi-natural and intensive silvicultural systems for the boreal mixedwood forest. For. Chron. 72: 286-292.

Lilja, S., M. De Chantal, T. Kuuluvainen, I. Vanha-Majamaa and P. Puttonen. 2005. Restoring natural characteristics in managed Norway spruce [Picea abies (L.) Karst.] stands with partial cutting, dead wood creation and fire: immediate treatment effects. Scan. J. For. Res. 20: 68-78, Supp. 6.

Liu, X.D., U. Silins, V.J. Lieffers and R.Z. Man. 2003. Stem hydraulic properties and growth in lodgepole pine stands following thinning and sway treatment. Can. J. For. Res. 33: 1295-1303.

MacDonald, G.B., M.L. Cherry and D.J. Thompson. 2004. Effect of harvest intensity on development of natural regeneration and shrubs in an Ontario boreal mixedwood stand. For. Ecol. Manag. 189: 207-222.

MacDonald, G.B. and D.J. Thompson. 2003. Responses of planted conifers and natural hardwood regeneration to harvesting, scalping, and weeding on a boreal mixedwood site. For. Ecol. Manag. 182: 213-230.

MacDonell, M.R. and A. Groot. 1997. Harvesting peatland black spruce: Impacts on advance growth and site disturbance. For. Chron. 73: 249-255.

Maguire, D.A., D.B. Mainwaring and C.B. Halpern. 2006. Stand dynamics after variable-retention harvesting in mature Douglas-fir forests of Western North America. Allg. Forst. Jagdztg. 177: 120-129. Martikainen, P., J. Kouki and O. Heikkala. 2006. The effects of green tree retention and subsequent prescribed burning on ground beetles (Coleoptera:Carabidae) in boreal pine-dominated forests. Ecography 29: 659-670.

McDowell, N., J.R. Brooks, S.A. Fitzgerald and B.J. Bond. 2003. Carbon isotope discrimination and growth response of old Pinus ponderosa trees to stand density reductions. Plant. Cell. Environ. 26: 631-644.

McRae, D.J., L.C. Duchesne, B. Freedman, T.J. Lynham and S. Woodley. 2001. Comparisons between wildfire and forest harvesting and their implications in forest management. Environ. Rev. 9: 223-260.

Mitchell, S.J. and W.J. Beese. 2002. The retention system: reconciling variable retention with the principles of silvicultural systems. For. Chron. 78: 397-403.
Moore, J.R., D.A. Maguire, D.L. Phillips and C.B. Halpern. 2002. Effects of varying levels of green-tree retention on amount of harvesting damage. W. J. Appl. For. 17: 202-206.

Moses, R.A. and S. Boutin. 2001. The influence of clear-cut logging and residual leave material on small mammal populations in aspendominated boreal mixedwoods. Can. J. For. Res. 31: 483-495.

Navratil, S., L.G. Brace, E.A. Sauder and S. Lux. 1994. Silvicultural and harvesting options to favour immature white spruce and aspen regeneration in boreal mixedwoods. Canadian Forest Service, Northern Forestry Centre, Edmonton, AB. Information Report NOR-X-337.

Ontario Ministry of Natural Resources (OMNR). 2001. Forest Management Guide for Natural Disturbance Pattern Emulation. Queen's Printer. Peterborough, Ontario. Available at http://www.mnr.gov.on.ca/mnr/forests/forestdoc/ebr/guide/natural_dist/part\%20one.pdf.

Prudham, W.S. 2005. Knock on Wood: Nature as Commodity in Douglas-fir Country. Routledge, New York. 259 p.

Ruel, J.-C. 1989. Mortalité du bois laissé sur pied à la suite d'une coupe par bandes dans trois régions du Québec. For. Chron. 65: 107-113.

Ruel, J.-C. 1995. Understanding windthrow: silvicultural implications. For. Chron. 71: 434-445.

Ruel, J.-C., D. Pin and K. Cooper. 2001. Windthrow in riparian buffer strips: effect of wind exposure, thinning and strip width. For. Ecol. Manag. 143: 105-113.

Ruel, J.-C, P. Raymond and M. Pineau. 2003. Windthrow after shelterwood cutting in balsam fir stands. N. J. Appl. For. 20: 5-13.

Scarratt, J.B. 2001. Black sturgeon boreal mixedwood research project: Establishment report. Canadian Forest Service, Great Lakes Forestry Centre, Sault Ste. Marie, Ontario.

Scott R.E. and S.J. Mitchell. 2005. Empirical modelling of windthrow risk in partially harvested stands using tree, neighbourhood, and stand attributes. For. Ecol. Manag. 218: 193-209.

Sist, P. and N. Nguyen-The. 2002. Logging damage and the subsequent dynamics of a dipterocarp forest in East Kalimantan (1990-1996) For. Ecol. Manag. 165: 85-103.

Smith, D.M., B.C. Larson, M.J. Kelty and P.M.S. Ashton. 1997. The Practice of Silviculture: Applied Forest Ecology. $9^{\text {th }}$ Edition. John Wiley and Sons, New York. 560 p.

Tallman, J.L. 1998. Planning and operating manual: harvesting with regeneration protection. Lake Abitibi Model Forest and Abitibi Consolidated. 17 p.

Thorpe, H.C., S.C. Thomas and J.P. Caspersen. Residual-tree growth responses to partial stand harvest in the black spruce (Picea mariana) forest. (In review).

Urban, S.T., V.J. Lieffers and S.E. MacDonald. 1994. Release in radial growth in the trunk and structural roots of white spruce as measured by dendrochronology. Can. J. For. Res. 24: 1550-1556.

Vanderwel, M.C., J.R. Malcolm and S.C. Mills. A meta-analysis of forest bird responses to partial retention harvesting. In press.

Walter, S.T. and C.C. Maguire. 2004. Conifer response to three silvicultural treatments in the Oregon Coast Range foothills. Can. J. For. Res. 34: 1967-1978.

Whitney, R.D., R.L. Fleming, K. Zhou and D.S. Mossa. 2002. Relationship of root rot to black spruce windfall and mortality following strip clear-cutting. Can. J. For. Res. 32: 283-294.

Wiser, S.K., R.B. Allen, U. Benecke, G. Baker and D. Peltzer. 2005. Tree growth and mortality after small-group harvesting in New Zealand old-growth Nothofagus forests. Can. J. For. Res. 35: 2323-2331.

Youngblood, A.P. 1991. Radial growth after a shelterwood seed cut in a mature stand of white spruce in interior Alaska. Can. J. For. Res. 21: $410-413$. 